Науковий аналіз проблеми організації профільного навчання старшокласників у загальноосвітніх навчальних закладах в Україні дозволяє зробити висновок, що профільне навчання старшокласників має спрямовуватися на підготовку молодої людини до свідомого вибору подальшої професійної діяльності, що сприяє іiі адаптації до життя у швидкозмінному світі.

Розроблена та обгрунтована модель психологічного супроводу формування цілісності особистості учня в умовах загальноосвітнього навчального закладу 3 профільного навчання старшокласників містить підготовчу та основну підсистеми, визначає мету, завдання, напрями діяльності педагогічного колективу на різних етапах профільного навчання.

Основна підсистема роботи загальноосвітнього навчального закладу 3 профільного навчання старшокласників спрямована на формування свідомого професійного самовизначення старшокласників, отримання ними профільної освіти як складника допрофесійної підготовки, тобто опанування теоретичними знаннями i практичними навичками професії за обраним профілем, підготовку до майбутнього навчання або роботи.

Підкреслюється роль психолого-педагогічної діагностики у формуванні профільних класів і груп профільного навчання старшокласників.

Доведено доцільність впровадження в систему роботи загальноосвітнього навчального закладу психолого-педагогічної служби, яка виключає чинник випадковості і невмотивованості професійного самовизначення старшокласників, їх подальшого профільного навчання; забезпечує добір учнів до профільних класів.

\title{
Література
}

1. Авдієвська О. П. Особливості соціалізації підлітка в умовах швидких соціальних змін / О. П. Авдієвська, С. О. Баклушинський. - К., 1990. - 223 с. 2. Варбан М. Ю. Рефлексія професійного становлення в юнацькому віці/ М. Ю. Варбан //Практична психологія та соціальна робота. -1998. - № 6-7.- С. 80-83. 3. Пряжников Н. Субъект профессионального и личностного самоопределения / Н. Пряжников, О. Пряжникова // Школьный психолог. - 2001. - № 19. - С. 7. 4. Пряжніков Н. Особиста професійна перспектива / Н. Пряжніков // Психолог. 2004. - № 16. - С. 6-8. 5. Сидоренко В. Наукові основи професійного самовизначення школярів. Соціально-психологічні передумови вибору професії / В. Сидоренко // Трудова підготовка у закладах освіти. - 1999. - № 1. - С. 33-39. 6. Туріщева Л. В. Психологічне супроводження профільного навчання / Л. В. Туріщева. - Х. : Основа, 2007. - 144 с. 7. Фридман Л. М. Изучение личности учащихся и ученических коллективов / Л. М. Фридман, Т. А. Пушкина, И. Я. Каплунович. - М. : Просвещение, 1988. -207 c.

УДК 378. 147

Ірина Козаченко

\section{ВИКОРИСТАННЯ ІННОВАЦЙНИХ ТЕХНОЛОГІЙ У ВИХОВНОМУ ПРОЦЕСІ ВИЩОГО НАВЧАЛЬНОГО ЗАКЛАДУ}

Козаченко I. В. Використання інноваційних технологій у виховному процесі вищого навчального закладу.

У статті розглянуто особливості використання інноваційних педагогічних технологій у виховному процесі вищого навчального закладу. Навчання 3 використанням інноваційних технологій інтегрує процеси, які не можна об'єднувати в межах професійної компетенції викладачів і рівнів їхньої готовності до інноваційної 
діяльності. Подані рекомендації щодо ефективного впровадження інноваційних технологій у навчально-виховний процес. Перспективами $є$ детальний подальший розгляд використання інноваційних педагогічних технологій у виховному процесі BH3.

Ключові слова: інноваційні технології, інноватика, навчально-виховний процес ВН3; освітній простір України.

Козаченко И. В. Использование инновационных технологий в воспитательном процессе высшего учебного заведения.

В статье рассмотрены особенности использования инновационных педагогических технологий в воспитательном процессе вуза. Обучение с использованием инновационных технологий интегрирует процессы, которые нельзя объединять в рамках профессиональной компетенции преподавателей и уровней их готовности к инновационной деятельности. Даны рекомендации с целью эффективного внедрения инновационных технологий в учебно- воспитательный процесс. Перспективами является детальное дальнейшее рассмотрение использования инновационных педагогических технологий в воспитательном процессе вуза.

Ключевые слова: инновационные технологии, инновация, учебновоспитательный процесс вузов; образовательное пространство Украины.

Kozachenko I. V. Use of innovation technologies in the educational process of higher educational institution.

The article discusses the features of the innovative educational technologies in the educational process of higher education. Learning with Innovative Technologies integrates processes that should not be combined within the professional competence of teachers and their level of readiness for innovation. Recommendations for the effective implementation of innovative technologies in the educational process are submited. Perspective is detailed, further consideration of the use of innovative educational technologies in the educational process of the university.

Key words: innovation technologies, Innovation , educational process of higher school; educational space of Ukraine.

Сучасне суспільство характеризується швидкими змінами в усіх галузях життя, що суттєво впливає на розвиток інформаційного, зокрема й освітнього простору. Освітня галузь, яка $\epsilon$ основоположницею формування світогляду, духовного становлення особистості, зазнає значних трансформаційних процесів. Простір, де стикаються нові цінності й технології, нові стилі життя, вимагає нових, сучасних освітніх підходів. Гуманізація освіти, іiі орієнтація на розкриття особистісного потенціалу зумовили виникнення й удосконалення нових освітніх технологій. Тому вимогою сьогодення стає апробація й упровадження інноваційних освітніх технологій у навчально-виховний процес. Національна стратегія розвитку освіти в Україні на період до 2021 року визначає запровадження освітніх інновацій як один із пріоритетних напрямів державної політики в освітній галузі.

Проблема розвитку інноваційного потенціалу вчителя в останні десятиліття широко розглядається в роботах М. Кларіна, В. Ляудіса, Л. Подимової, С. Полякова, Н. Юсуфбекова, у яких розкривається сутність нововведень у галузі освіти. Науковому обгрунтуванню системи управління інноваційними процесами, визначенню критеріїв оцінки діяльності викладачів-новаторів присвячені дослідження В. Кваші, Н. Коноплін, В. Лазарєва, М. Поташника, А. Тубельского, Т. Шамовой, 
О. Хмарка. Механізми педагогічної творчості, що є основою інноваційної діяльності викладача, проаналізовано в працях В. Загвязинского, С. Слканова, В. Кан-Калика, Н. Кухарева, В. Ляудіс, А. Маркової, Л. Митіної, Л. Фрідмана. Проблемою упровадження інноваційних технологій у навчально-виховний процес ВНЗ України та світу опікувалися: Л. Подимова, Д. Мазоха, Н. Опанасенко, Т. Ярова, В. Химинець, Т. Грабовська, М. Талапканич, Я. Сивохоп, В. Петрус, М. Фіцула, В. Ягупов, В. Кремінь, 3. Абасов та інші.

Метою статmi $\epsilon$ розкрити і показати важливе значення використання інноваційних педагогічних технологій у виховному процесі ВН3.

Досвід та успіхи найбільш розвинених країн світу в галузі науки, виробництва нових технологій свідчать про необхідність перебудови системи освіти у напрямку створення умов для особистості, яка має вільно виявляти свої здібності, розвиватися відповідно до своїх нахилів. Сучасні науковці розглядають процес створення, поширення та використання нових засобів в освіті як інновацію. У перекладі 3 грецької мови «інновація» означає оновлення, новизна, зміна. Інновація як процес означає часткову або масштабну зміну стану системи і відповідну діяльність людини. Інновація як результат передбачає процес створення нового, що має конкретну назву «новація». Також вона відображає наявні знання, вміння, навички та індивідуальні риси особистості. Освітня інновація характеризується новизною в галузі психологопедагогічних, соціально-економічних та науково-виробничих досліджень, спрямованих на якісне поліпшення освітнього процесу. В Україні триває реформування системи освіти. Інструментом становлення нової освіти $є$ інноваційна діяльність, яка полягає у внесенні якісно нових елементів у навчально-виховний процес, які сприятимуть створенню компетентних фахівців, знавців своєї справи.

Інноваційна педагогічна діяльність заснована на осмисленні практичного педагогічного досвіду. Це цілеспрямована педагогічна діяльність, зорієнтована на зміну та розвиток навчально-виховного процесу задля досягнення вищих результатів, одержання нового знання, формування якісно іншої педагогічної практики. Інноваційна спрямованість визначається критеріями педагогічних інновацій, до яких відносять: новизну, оптимальність, результативність та ефективність, можливість творчого застосування нових результатів у майбутньому досвіді [4, с. 240]. Тож велике значення має упровадження інноваційних педагогічних технологій.

Інноваційна педагогічна технологія - це цілеспрямоване, систематичне й послідовне упровадження у практику оригінальних, новаторських способів, прийомів педагогічних дій і засобів, що охоплюють цілісний навчально-виховний процес від визначення його мети до очікуваних результатів.

Розроблено різні підходи в обгрунтуванні необхідності упровадження інноваційних педагогічних технологій у сучасну освіту. 3 упровадженням у навчально-виховний процес сучасних технологій викладач все більше набуває функції консультанта, порадника, наставника. Останнє вимагає від нього спеціальної психолого-педагогічної підготовки, оскільки у професійній діяльності викладача реалізуються не тільки спеціальні предметні знання, але й сучасні психологопедагогічні знання, знання структури технологій навчання і виховання. На цій базі формується готовність до сприйняття, оцінки і реалізації педагогічних інновацій.

Задля успішної роботи в області інноваційної педагогіки викладач повинен володіти такими характеристиками:

- творчою здатністю генерувати і продукувати нові уявлення та ідеї, проектувати і моделювати їх у практичних формах, конкретній діяльності;

- культурно-естетичної розвиненістю й освіченістю, що передбачає 
інтелектуальну й емоційну розвиненість і високий рівень культурної грамотності педагога;

- відкритістю особистості до нового, що базується на толерантності особистості і гнучкості мислення.

Студенти вчаться, коли мають мотивацію до пізнання чогось нового, корисного, позитивного. Підвищити мотивацію до навчання можна лише тоді, коли посилатися на справжні потреби тих, хто навчається, і створити умови для їх забезпечення. Студенти повинні думати, розуміти суть речей, осмислювати ідеї та концепції і вже на основі цього вміти шукати потрібну інформацію, трактувати іiі та застосовувати в конкретних умовах, формулювати і відстоювати особисту думку. Саме цьому сприяють інноваційні технології, використання яких не є самоціллю, не лише засобом для досягнення такої атмосфери в аудиторії, яка найкраще сприяє співробітництву, порозумінню й доброзичливості, надає змогу реалізувати особистісно орієнтоване навчання, виховати компетентну особистість. Щоб створити умови для розвитку i саморозвитку студентів, виховати в них уміння приймати самостійні рішення, треба реалізувати інноваційні технології в системі освіти на кожному занятті. Це залежить від особистості викладача, його професійної майстерності, ставлення до реалій сучасного життя.

Ефективність діяльності на занятті 3 використанням інноваційних технологій залежить насамперед від благополуччя в соціально-психологічному аспекті. Студент буде активним, якщо його не лякає атмосфера заняття, що складається 3 різних аспектів його власної діяльності й діяльності викладача. Студент активний, якщо на занятті відсутня критика його особистості з боку викладача або одногрупників, а зауваження мають конструктивний характер і стосуються насамперед результатів його діяльності. Він відчуває себе в безпеці, якщо будь-який його внесок у навчальний процес ціниться. Тільки за відсутності страху перед тим новим, що пропонує педагог, студент дозволить собі експериментувати з моделями поведінки, знаходячи оптимальний результат своєї поведінки, визначаючи свою роль у спільній роботі, обираючи і формуючи свою позицію, свою точку зору. Для ефективного застосування інноваційних технологій, зокрема щоб охопити необхідний обсяг матеріалу і глибоко його вивчити, а не перетворити технології на безглузді «ігри заради ігор», педагог повинен старанно планувати свою роботу, щоб дати завдання студентам для попередньо підготовки, відібрати для заняття такі технології, які дали б студентам «ключ» до розуміння теми, під час інноваційних вправ дати студентам час подумати над завданням, щоб вони сприйняли його серйозно, а не механічно або «граючись» виконали його; на одному занятті недоцільно використовувати багато інноваційних вправ; проводити швидкі опитування, самостійні домашні роботи 3 різноманітних матеріалів теми, які не були пов'язані 3 інтерактивними вправами; важливим проведення спокійного глибокого обговорення за підсумками інтерактивної вправи, зокрема акцентуючи й увагу на іншому матеріалі теми. Для зміцнення контролю за ходом процесу навчання за умов використання інноваційних технологій вчитель повинен попередньо добре підготуватися: грунтовно вивчити та продумати матеріал, у тому числі додатковий; старанно спланувати і розробити заняття: визначити хронометраж, ролі учасників, підготувати запитання й можливі відповіді, виробити критерії оцінки ефективності заняття; мотивувати студентів до вивчення шляхом добору найбільш цікавих випадків, проблем; оголошувати очікувані результати заняття й критерії оцінки роботи студентів; передбачити різноманітні методи для привернення уваги, налаштування на роботу, дотримання дисципліни, необхідної для нормальної роботи в аудиторії; цьому можуть сприяти різноманітні 
вправи-розминки, письмовий розподіл ролей у групах.

Навчання з використанням інноваційних технологій якісно перевищує класичну освіту. Воно інтегрує процеси, які не можна об'єднувати в межах професійної компетенції викладачів і рівнів їхньої готовності до інноваційної діяльності.

Із метою реалізації головних положень науково-методичної проблеми й упровадження в практику роботи освітніх інноваційних технологій потрібно звернути увагу на основні педагогічні технології, які є найбільш поширеними у навчальновиховному процесі:

1. Інформаційні технології.

2. Проектні технології (забезпечують інтеграцію предметних знань і вмінь із різних предметів і видів діяльності).

3. Ігрові технології (формують навички розв'язувати творчі завдання на основі вибору альтернативних варіантів).

4. Технології особистісно зорієнтованого та диференційованого навчання.

5. Інтерактивні технології, (робота у групах, метод проектів, «мозковий штурм», «кейс-метод», ділові ігри, «відкритий мікрофон», групова дискусія, взаємонавчання).

6. Технології проблемного навчання.

7. Гуманістичне навчання.

8. Технологія життєтворчості.

9. Інтеграційна природнича освіта.

10. Колективне навчання.

11. Інтегративне навчання.

Зауважимо, що завдяки інноваційним педагогічним технологіям звичайне заняття перетворюється на заняття-практикум, заняття-пошук, заняття-дискусію, заняття-панораму тощо. Як було зазначено вище це сприяє насамперед підвищенню мотивації студентів до навчання, виховує в них почуття відповідальності, уміння знаходити вихід 3 проблемних ситуацій, а також обізнаність у певних видах діяльності.

Щоб створити умови для розвитку і саморозвитку студентів, виховати в них уміння приймати самостійні рішення, треба реалізовувати інноваційні педагогічні технології в системі освіти на кожному занятті. Це залежить від особистості викладача, його професійної майстерності, ставлення до реалій сучасного життя. Рекомендовано 3 метою ефективного упровадження інноваційних технологій у навчально-виховний процес провести певні заходи:

- Організувати виставку літератури 3 науково-методичного забезпечення інноваційних педагогічних технологій.

- Оформити педагогічний куточок «Досвід кращих - надбання кожного».

- Провести виставку - ярмарок педагогічних ідей викладачів університету.

- Провести тижні педагогічної майстерності «Прогресивні технології в методиці проведення семінарського заняття».

- Здійснювати університетський контроль упровадження інноваційних технологій на заняттях.

Інновації $є$ необхідним процесом еволюції освіти. Інновації реалізується через спеціальні педагогічні технології. Жодна інноваційна технологія не $\epsilon$ універсальною. Запровадження будь-яких інновацій потребує змін. Новітні технології потребують програмного і методичного забезпечення, знання методики запровадження інновацій. Інноваційні педагогічні технології відіграють важливу роль у навчально-виховному процесі вищого навчального закладу, оскільки сприяють підвищенню мотивації як 
студентів, так і викладачів до навчальної діяльності, поглибленння знань та підвищенню якості навчального процесу. Упровадження інноваційних технологій в освітньому просторі України з кожним роком посилюється і виходить на новий рівень. Найчастіше інноваційні ідеї пов'язані з розвитком комп'ютерно-технічної бази, відкриттям нових закономірностей психологічного розвитку людини тощо. Нині застосування поява нових методів викладання, роботи зі студентською молоддю за допомогою різних комп'ютерних програм, дистанційних курсів не $є$ чимось не звичайним. Студенти, молоді викладачі зазвичай звикають і швидко пристосовуються до інновацій у навчальному процесі, що, в свою чергу, сприяє взаємодії «студентвикладач», i навпаки - як у професійній, так і в міжособистісній площині. Тому освітній процес в Україні має численні перспективи в галузі інноватики, а українські дослідники не припиняють наукових розвідок з цієї галузі з метою піднести якість вітчизняної освіти на найвищий європейський щабель, відповідаючи передовим стандартам навчально-виховних критеріїв освіти.

\section{Література}

1. Абасов 3. А. Понятийно-терминологический апарат инновационной педагогической деятельности / 3. А. Абасов // Философия образования. - 2006. № 1 (15). - С. 56-62. 2. Алексюк А. М. Педагогіка вищої освіти України. Історія. Теорія // підручник [для студентів, аспірантів та молодих викладачів вищих навч. закладів] / А. М. Алексюк. - К. : Либідь, 1998. - 560 с. 3. Высоцкий С. И. Дидактическое основания конструирования процеса обучения / С. И. Высоцкий, В. В. Краевский // Новые иследования в педагогических науках. - М., 1986. Вып. 1 (47). 4. Глушман О. В. Системний аналіз поняття «технологія навчання у вузі»: матеріали міжнар. наук.-практ. конф. «Педагогічна технологія у сучасному

вузі». - Луцьк, 1995. - С. 34-38. 5. Дубасенюк О. А Інноваційні навчальні технології - основа модернізації університетської освіти / О. А. Дубасенюк // Освітні інноваційні технології у процесі викладання навчальних дисциплін: Зб. наук.-метод праць / за ред. О. А. Дубасенюк. - Житомир: Вид-во ЖДУ, 2004. - С. 3-14. 6. Козлова О. І. Основні стратегії педагогічного впливу при традиційному та інноваційному підходах до навчання / О. І. Козлова // Педагогічні інновації: ідеї, реалії, перспективи: [зб. наук. праць] / ред. кол. Л. І. Даниленко та ін. - К. : Логос, 2000. - С. 239-245. 7. Кремінь В. Г. Вища освіта в Україні і Болонський процес: [навч. посіб.]. - К. : Освіта, 2004. - 384 с. 8. Мазоха Д. С. Педагогіка: [навч. посіб.] / Д. С. Мазоха, Н. І. Опанасенко. - К. : Центр навчальної літератури, 2005. - 232 с. 9. Фіцула М. Педагогіка: [навч. посіб.] / М. Фіцула. - [2-ге вид., випр., доп.]. - К. : Академвидав, 2005. - 559 с. 10. Фурман А. В. Методологічний аналіз систем розливального навчання / А. В. Фурман // Педагогіка i психологія. - 1995. № 1. С. 22 -26. 11. Ягупов В. Педагогіка: [навч. посіб.] / В. Ягупов. - К. : Либідь, 2002. -559 c.

УДК $37.0: 354$

Олексій Крюков, Світлана Луценко

\section{ІННОВАЦІЙНА ОСВІТА ЯК ОДИН ІЗ ОСНОВНИХ РЕСУРСІВ МОДЕРНІЗАЦІЇ СУЧАСНОЇ ДЕРЖАВИ}

Крюков О. І., Луценко С. М. Інноваційна освіта як один із основних ресурсів модернізації сучасної держави.

У статті порушуються питання взаємозв'язку інноваційної освіти та розвитку держави, визначено принципи управління інноваційними освітніми процесами. 